\title{
Prediksi Dampak Jalan Tol terhadap Situs Arkeologi di Kecamatan Kalasan
}

\author{
Janati Prariyadiyani, Andri Kurniawan, M. Baiquni
}

Masuk: 12042021 / Diterima: 14072021 / Dipublikasi: 01122021

\begin{abstract}
Along with the rapid advancement of transportation technology since the 20th century, toll roads have become an inevitable necessity. On the other hand, the need for land for the construction of toll lanes and other supporting facilities and changes to the existing road network cannot negate the impact on the surrounding environment. One of the impacts that must be taken into account due to the Solo-Yogyakarta Toll Road in the Kalasan District, Sleman, Yogyakarta Special Region (DIY), involves the archaeological potential of this sub-district. Several archaeological remains of the Classical Period in the form of Hindu or Buddhist temples that have been designated as Cultural Conservation (CB) have not described the full potential that exists. Much data is still buried, considering that every temple must have a supporting component in the past built environment. These components can be in the form of remnants of other structures and loose finds buried by material from the eruption of Mount Merapi for hundreds of years. This article attempts to predict the positive and negative impacts of the construction of the Solo-Yogyakarta Toll Road on all archaeological potentials based on three criteria, namely: directly affected (by the construction of toll roads and supporting facilities), indirectly affected (by other road developments), and not affected. Through spatial analysis, each of these criteria is mapped as a predictive research result. Several recommendations were formulated as input for related parties engaged in research, cultural heritage preservation, and local government.
\end{abstract}

Key words: Toll Road; Impact Prediction; Cultural Heritage; Classical Period; Predictive Research

Abstrak Seiring pesatnya kemajuan teknologi transportasi yang terjadi sejak abad ke-20, jalan tol menjadi kebutuhan yang tidak terelakkan. Di sisi lain, kebutuhan lahan untuk pembangunan jalur tol dan sarana pendukung lainnya, begitu pula perubahan pada jaringan jalan yang sudah ada, tidak dapat meniadakan dampak terhadap lingkungan sekitarnya. Salah satu dampak yang harus diperhitungkan akibat pembangunan Jalan Tol Solo-Yogyakarta di wilayah Kecamatan Kalasan, Sleman, Daerah Istimewa Yogyakarta (DIY) ada hubungannya dengan potensi arkeologi yang dimiliki kecamatan ini.-Sejumlah tinggalan arkeologi Periode Klasik berupa candi Hindu atau Buddha yang sudah ditetapkan sebagai Cagar Budaya (CB) belum menggambarkan keseluruhan potensi yang ada. Banyak data yang masih terkubur mengingat bahwa setiap candi pasti memiliki komponen pendukung di dalam lingkungan binaan masa lalu. Komponen tersebut dapat berupa sisa bangunan lain struktur, maupun temuan lepas yang terkubur oleh material hasil erupsi Gunung Merapi selama ratusan tahun. Artikel ini berusaha memprediksi dampak positif dan negatif pembangunan Jalan Tol Solo-Yogyakarta terhadap seluruh potensi arkeologi berdasarkan tiga kriteria, yakni: terdampak langsung (oleh pembangunan jalan tol dan fasilitas pendukung), terdampak tidak langsung (oleh perkembangan jalan lain), dan tidak terdampak. Melalui analisis keruangan masing-masing kriteria tersebut dipetakan sebagai hasil penelitian yang bersifat prediktif. Beberapa rekomendasi dirumuskan sebagai masukan bagi pihak-pihak terkait yang bergerak di bidang penelitian, pelestarian warisan budaya, serta pemerintah daerah setempat.

Kata kunci: Jalan Tol; Prediksi Dampak; Cagar Budaya; Periode Klasik; Penelitian Prediktif

This is an open access article under the CC BY-SA license.

Copyright (C) 2021 by Author. Published by Universitas Pendidikan Ganesha.

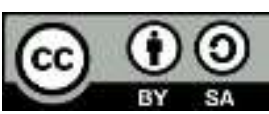


Prediksi Dampak Jalan Tol terhadap Situs Arkeologi di Kecamatan Kalasan/Janati Prariyadiyani, Andri Kurniawan, M. Baiquni

\section{Pendahuluan}

Era kepemimpinan Presiden Joko Widodo merupakan era pembangunan infrastruktur fisik secara besar-besaran di Indonesia, khususnya di bidang transportasi darat. Tercatat lebih dari $1.200 \mathrm{~km}$ jalan tol yang sudah dibangun maupun sedang direncanakan di beberapa pulau selama kurun waktu 2015 hingga sekarang. Badan Pengatur Jalan Tol (BPJT) Kementerian Pekerjaan Umum dan Perumahan Rakyat mencatat perkembangan pembangunan jalan tol di Indonesia sejak 1978 hingga sekarang. Selain itu, dibangun pula jalan tol Solo-Yogyakarta-BawenCilacap yang perencanaannya mulai digodok tahun 2019.

Peraturan Gubernur Daerah Istimewa Yogyakarta (DIY) Nomor 206/KEP/2020, Tanggal 10 Juli 2020, tentang Penetapan Lokasi Pembangunan Jalan Tol Solo-
Yogyakarta di DIY, menyebutkan bahwa penetapan atas lokasi pembangunan Jalan Tol SoloYogyakarta di DIY digunakan sebagai izin untuk pengadaan tanah, perubahan penggunaan tanah, dan peralihan hak atas tanah. Lokasi yang dimaksud mencakup luas $1.774 .352 \mathrm{~m}^{2}$ (satu juta tujuh ratus tujuh puluh empat tiga ratus lima puluh dua meter persegi), meliputi 14 desa di enam kecamatan di Kabupaten Sleman. Keenam kecamatan tersebut yakni: (1) Kecamatan Prambanan (Desa Bokoharjo); (2) Kecamatan Kalasan (Desa Selomartani, Tamanmartani, Tirtomartani, dan Purwomartani); (3) Kecamatan Depok(Desa Maguwoharjo, Condong Catur, dan Catur Tunggal); (4) Kecamatan Ngaglik (Desa Sariharjo); (5) Kecamatan Gamping (Desa Trihanggo); dan (6) Kecamatan Mlati (Desa Sinduadi, Sendangadi, Tlogoadi, dan Tirtoadi) (Gambar 1).

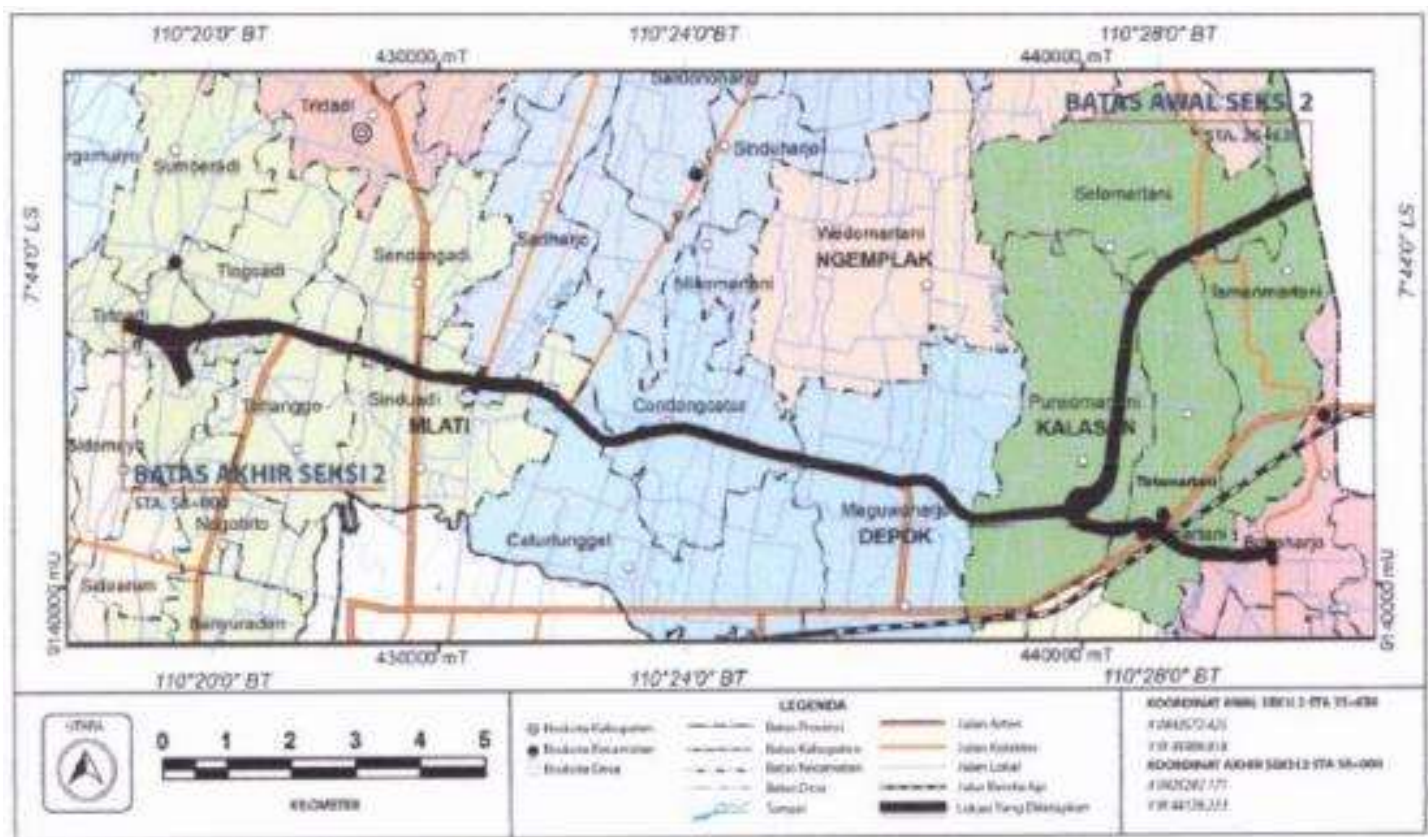

Gambar 1. Peta lokasi rencana pembangunan jalan tol Solo - Yogyakarta di D.I. Yogyakarta (Sumber: Keputusan ubernur DIY Nomor 206/KEP/2020) 
Prediksi Dampak Jalan Tol terhadap Situs Arkeologi di Kecamatan Kalasan/Janati Prariyadiyani, Andri Kurniawan, M. Baiquni

Berbeda dengan pembangunan infrastruktur fisik lainnya, pembangunan jalan memiliki implikasi lebih luas karena menyangkut jaringan transportasi yang melibatkan banyak komponen, mulai dari pemilihan trasenya hingga pengelolaannya. Persoalan pembangunan jalan tol menjadi semakin krusial jika dikaitkan dengan sumberdaya lahan di mana infrastruktur tersebut dibangun. Lahan yang tidak saja produktif tetapi juga memiliki nilai kultural tinggi merupakan salah satu contoh dari persoalan dimaksud.

Kondisi lahan seperti di atas dijumpai khususnya di wilayah Sleman bagian timur yang banyak mengandung cultural landmarks berupa monumen- monumen arkeologis yang hampir semuanya sudah ditetapkan sebagai CB. Proteksi hukum yang ditetapkan melalui Undang-undang $11 / 2010$ tentang CB menjadikan monumen-monumen tersebut sebagai bangunan bersejarah yang dilindungi. Di luar itu, kemungkinan adanya situs dan objek-objek arkeologis lain masih tinggi, mengingat bahwa bangunan umumnya memiliki konteks keruangan dengan komponen-komponen pendukungnya. Apalagi jika bangunan tersebut bukan bersifat tunggal, melainkan membentuk klaster yang beberapa di antaranya berupa kompleks percandian.

\footnotetext{
${ }^{1}$ Janati Prariyadiyani, ${ }^{1}$ Andri Kurniawan, ${ }^{1} \mathrm{M}$. Baiquni

${ }^{1}$ Universitas Gadjah Mada, Indonesia
}

prariyajanati@gmail.com

\begin{abstract}
Dalam perkembangannya di Indonesia, Arkeologi Klasik merupakan salah satu kajian yang berfokus pada tinggalan-tinggalan dari masa Hindu- Buddha dengan temuan utama candi dan komponenkomponennya. Kalasan-

Prambanan termasuk salah satu wilayahdi DIY yang memiliki kerapatan tinggalan periode klasik tinggi. Yuwono (2015), melalui pemodelan prediktif, bahkan menempatkan wilayah ini sebagai klaster candi terpadat di DIY dibandingkan dua klaster lainnya, yaitu Klaster Seyegan- Mlati dan Cangkringan. Hipotesis ini didasarkan atas tiga variabel, yakni jarak antar situs (site distance); jumlah situs per grid berukuran $1 \times 1 \mathrm{~km}$; dan properti situs yang ditentukan berdasarkan kriteria eksisting data (non-building, single building, dan complex building) (Yuwono 2015, Gambar 2). Di dalam Peta KCB Prambanan yang dibuat oleh Dirjenbud tahun 2016, Klaster KalasanPrambanan hasil pemodelan prediktif tersebut berada di sisi barat kawasan yang masuk wilayah DIY (Gambar 2).
\end{abstract}

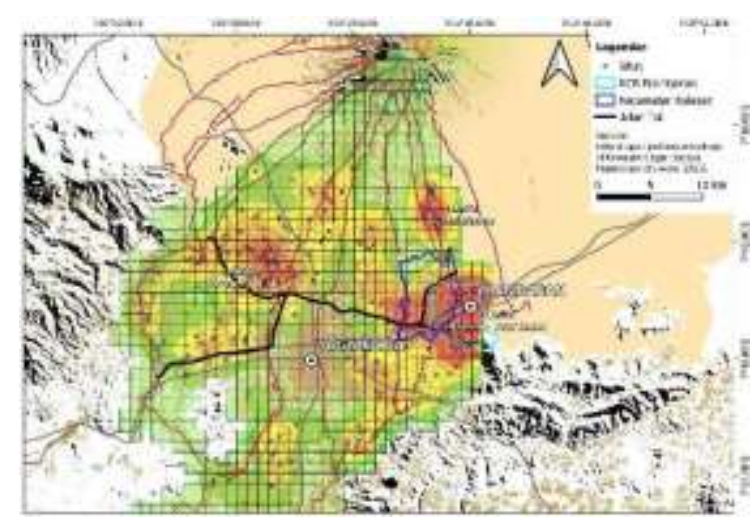

Gambar 2. Peta pemodelan prediktif potensi arkeologi di DIY Sumber: Yuwono (2015) 
Prediksi Dampak Jalan Tol terhadap Situs Arkeologi di Kecamatan Kalasan/Janati Prariyadiyani, Andri Kurniawan, M. Baiquni

Di luar hasil prediksi di atas, banyak temuan lepas di luar batasbatas situs yang sudah ditetapkan sebagai CB. Data lain yang diperoleh melalui survei georadar di sekitar Candi Kedulan memperoleh indikator keberadaan pagar keliling di luar area candi yang sudah diekspos saat ini (Husein et al. 2010). Data ini memperkuat keyakinan penulis bahwa wilayah Kalasan yang dilewati tapak Jalan Tol Solo-

Yogyakarta sebagaimana ditetapkan melaluiPeraturan Gubernur DIY Nomor 206/KEP/2020, merupakan wilayah padat temuan. Kemungkinan munculnya dampak pembangunan jalan tol terhadap warisan budaya yang ada tidak dapat dihindari. Permasalahan utama yang dapat dikemukakan melalui tulisan ini yakni: Bagaimana prediksi dampak positif dan negatif pembangunan Jalan Tol SoloYogyakarta di Kecamatan Kalasan terhadap potensi arkeologi baik yang sudah ditetapkan maupun yang baru diduga sebagai $\mathrm{CB}$ ?

\section{Metode}

Penelitian ini menggunakan analisis spasial melalui tumpang susun (overlay) antara hasil pemodelan prediktif yang sudah dilakukan sebelumnya (Yuwono 2015); sebaran situs klasik di Kawasan Cagar Budaya Prambanan (Dirjenbud RI 2016; Yuwono 2015; Mundardjito 2002; ditambah hasil observasi mandiri tahun 2020); dan Peta Rancangan Jalan Tol Solo-Yogyakarta di DIY (Peraturan Gubernur DIY Nomor 206/KEP/2020).

Objek utama yang dianalisis berupa jaringan jalan dan situs arkeologi dengan variabel sebagai berikut:

1. Jaringan Jalan (Gambar 2 dan Tabel 2):

1) Kategori jalan: rancangan jalur tol serta eksisting jalan nasional dan kabupaten. Rancangan jalur tol didasarkan atas data dari Bappeda Kabupaten Sleman dan Kep. Gub. DIY 117/KEP/2016, sedangkan eksisting jalan lainnya diambil dari Peta Rupa Bumi (RBI) Indonesia.

2) Konstruksi jalan: at grade atau elevated. Konstruksi at grade diartikan sebagai konstruksi jalan pada permukaan topografi, sedangkan konstruksi elevated merupakan konstruksi yang memerlukan tiang penyangga jalan, termasuk beberapa lingkar susun).

2. Situs Arkeologi (Gambar 3 dan Tabel 3):

1) Status: $C B$ atau bukan $C B$

Suatu objek, baik benda, bangunan, situs, maupun kawasan dinyatakan statusnya sebagai $C B$ dan memiliki kekuatan hukum sebagai CB jika objek tersebut sudah ditetapkan melalui SK Bupati, Gubernur, atau Menteri (UU 11/2010 tentang Cagar Budaya).

2) Sifat temuan: Bangunan atau struktur baik tunggal maupun kompleks (unmovable) atau komponen bangunan/temuan lepas (movable). Perbedaan antara unmovable (tak bergerak) dan movable (bergerak) terletak 
Prediksi Dampak Jalan Tol terhadap Situs Arkeologi di Kecamatan Kalasan/Janati Prariyadiyani, Andri Kurniawan, M. Baiquni

pada sifat dan kualitasnya. Secara keruangan, objek-objek unmovable memiliki kualitas yang lebih tinggi karena dapat mempertahankan konteksnya. Candi adalah salah satu contoh objek tak bergerak dengan tapak yang tidak terpindahkan, meskipun komponenkomponennya dapat saling terpisah dan bersifat terpindahkan akibat perubahan selama kurun waktu tertentu (proses transformasi).

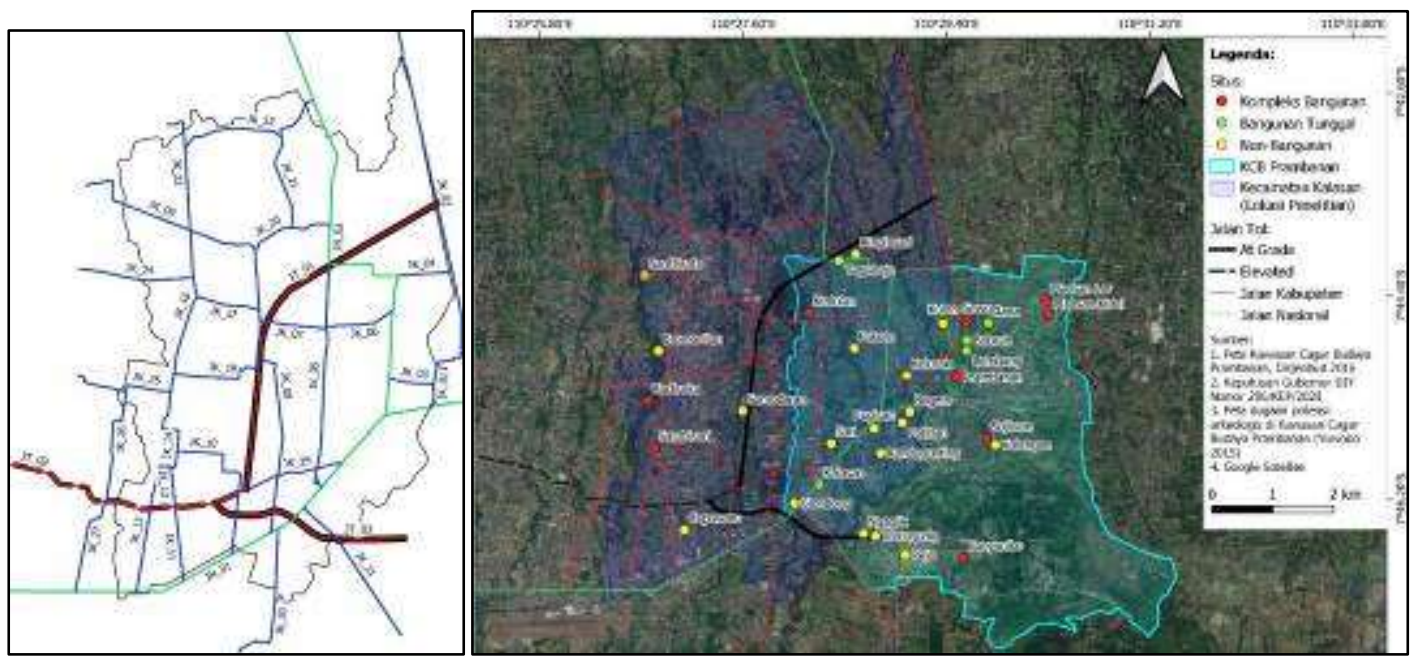

Gambar 3. Peta sebaran situs di Kecamatan Kalasan dan Kawasan Cagar Budaya Prambanan (kanan); dan jaringan jalan di area penelitian (kiri).

Tabel 2. Kategori jalan di area penelitian

\begin{tabular}{|c|c|c|c|c|c|c|}
\hline NO & KODE & RUAS & KATEGORI & KONSTRUKSI & $\begin{array}{l}\text { PANJANG } \\
(\mathrm{KM})\end{array}$ & $\begin{array}{l}\text { LEBAR } \\
(\mathrm{M})\end{array}$ \\
\hline 1 & JT_01 & SOLO - JOGJA & Jalan Tol & At Grade & 6.32 & 90 \\
\hline 2 & JT_02 & SOLO - JOGJA & Jalan Tol & Elevated & 13.73 & 90 \\
\hline 3 & JT_03 & JOGJA - CILACAP & Jalan Tol & At Grade & 3.35 & 90 \\
\hline 4 & JT_04 & JOGJA - BAWEN & Jalan Tol & Elevated & 10.67 & 90 \\
\hline 5 & JT_04 & JOGJA - BAWEN & Jalan Tol & Elevated & 10.67 & 90 \\
\hline 6 & JT_05 & JOGJA - CILACAP & Jalan Tol & Elevated & 5.14 & 90 \\
\hline 7 & JT_06 & JOGJA - CILACAP & Jalan Tol & At Grade & 11.64 & 90 \\
\hline 8 & JN_01 & $\begin{array}{l}\text { JL. JANTI - } \\
\text { PRAMBANAN }\end{array}$ & Jalan Nasional & At Grade & 10.15 & 17 \\
\hline 9 & JN_02 & $\begin{array}{l}\text { JL. PAKEM - } \\
\text { KALASAN }\end{array}$ & Jalan Nasional & At Grade & 20.57 & 5.5 \\
\hline 10 & JK_01 & $\begin{array}{l}\text { Jl. Taman Prambanan } \\
\text { Kulon }\end{array}$ & Jalan Kabupaten & At Grade & 1.17 & 6.5 \\
\hline 11 & JK_02 & Jl. Kikis Taskumbang & Jalan Kabupaten & At Grade & 6.22 & 5.5 \\
\hline 12 & JK_03 & Jl. Karangmojo & Jalan Kabupaten & At Grade & 0.75 & 4.5 \\
\hline 13 & JK_04 & Jl. Raya Prambanan & Jalan Kabupaten & At Grade & 0.91 & 4.5 \\
\hline 14 & JK_05 & Jl. Raya LPMP & Jalan Kabupaten & At Grade & 3.94 & 7.5 \\
\hline 15 & JK_06 & Jl. Pundung-Babadan & Jalan Kabupaten & At Grade & 1.2 & 5.5 \\
\hline 16 & JK_07 & Jl. Raya Kalimati & Jalan Kabupaten & At Grade & 1.11 & 5.5 \\
\hline 17 & JK_08 & Jl. Cangkringan & Jalan Kabupaten & At Grade & 4.97 & 4.5 \\
\hline 18 & JK_09 & Jl. Raya Selomartani & Jalan Kabupaten & At Grade & 3.29 & 5.5 \\
\hline
\end{tabular}


Prediksi Dampak Jalan Tol terhadap Situs Arkeologi di Kecamatan Kalasan/Janati Prariyadiyani, Andri Kurniawan, M. Baiquni

\begin{tabular}{|c|c|c|c|c|c|c|}
\hline 19 & JK_10 & Jl. Cupuwatu & Jalan Kabupaten & At Grade & 2.71 & 4.5 \\
\hline 20 & JK_11 & JI. UKRIM & Jalan Kabupaten & At Grade & 1.24 & 4.5 \\
\hline 21 & JK_12 & Jl. Kadirojo 2 & Jalan Kabupaten & At Grade & 0.66 & 5.5 \\
\hline 22 & JK_13 & Jl. Candi Sambisari & Jalan Kabupaten & At Grade & 2.12 & 4.5 \\
\hline 23 & JK_14 & $\begin{array}{l}\text { Jl. Ruko Candi } \\
\text { Sambisari }\end{array}$ & Jalan Kabupaten & At Grade & 1.15 & 4.5 \\
\hline 24 & JK_15 & Jl. Candi Sambisari & Jalan Kabupaten & At Grade & 0.66 & 5.5 \\
\hline 25 & JK_16 & Jl. Purwomartani & Jalan Kabupaten & At Grade & 2.76 & 5.5 \\
\hline 26 & JK_17 & Jl. Grenjeng & Jalan Kabupaten & At Grade & 1.06 & 4.5 \\
\hline 27 & JK_18 & Jl. Japlaksari & Jalan Kabupaten & At Grade & 0.39 & 4 \\
\hline 28 & JK_19 & Jl. Abiyoso & Jalan Kabupaten & At Grade & 1.36 & 4 \\
\hline 29 & JK_20 & Jl. Raya Selomartani & Jalan Kabupaten & At Grade & 1.42 & 4.5 \\
\hline 30 & JK_21 & Jl. Selamat & Jalan Kabupaten & At Grade & 1.62 & 6.5 \\
\hline 31 & JK_22 & Jl. Kaliwaru & Jalan Kabupaten & At Grade & 2.65 & 4.5 \\
\hline 32 & JK_23 & Jl. Cangkringan & Jalan Kabupaten & At Grade & 2.07 & 4.5 \\
\hline 33 & JK_24 & Jl. Raya Sambiroto & Jalan Kabupaten & At Grade & 1.91 & 4.5 \\
\hline 34 & JK_25 & Jl. Raya Kadisoka & Jalan Kabupaten & At Grade & 0.83 & 4.5 \\
\hline 35 & JK_26 & Jl. P. Diponegoro & Jalan Kabupaten & At Grade & 2 & 4.5 \\
\hline 36 & JK_27 & Jl. Anggrek & Jalan Kabupaten & At Grade & 1.69 & 4.5 \\
\hline 37 & JK_28 & Jl. Kadisoka & Jalan Kabupaten & At Grade & 0.9 & 5.5 \\
\hline 38 & JK_29 & Jl. Selokan Mataram & Jalan Kabupaten & At Grade & 1.73 & 4 \\
\hline 39 & JK_30 & Jl. Berbah - Kalasan & Jalan Kabupaten & At Grade & 4.11 & 5.5 \\
\hline 40 & JK_31 & Jl. Opak Raya & Jalan Kabupaten & At Grade & 2.68 & 5.5 \\
\hline
\end{tabular}

Sumber: Pengolahan Data (2021)

Keterangan:

JT: Jalan Tol $\quad$ : Sumber Bappeda Kab. Sleman dan Kep Gub DIY 117/KEP/2016

JN: Jalan Nasional : Sumber BIG

JK: Jalan Kabupaten : Sumber BIG

Tabel 3. Situs arkeologi di area penelitian

\begin{tabular}{r|lllll}
\hline NO & NAMA & STATUS & SIFAT & TEMUAN & KATEGORI \\
\hline 1 & Banyunibo & CB & Unmovable & Candi & Kompleks Bangunan \\
2 & Bogem & Belum CB & Movable & Komponen candi & Non-bangunan \\
3 & Bromonilan & Belum CB & Movable & Komponen candi & Non-bangunan \\
4 & Bubrah & CB & Unmovable & Candi & Bangunan Tunggal \\
5 & Bugisan & Belum CB & Movable & Komponen candi & Non-bangunan \\
6 & Cupuwatu & Belum CB & Movable & Komponen candi & Non-bangunan \\
7 & Gana & CB & Movable & Komponen candi & Non-bangunan \\
8 & Glondong & Belum CB & Movable & Komponen candi & Non-bangunan \\
9 & Kadisoka & CB & Unmovable & Candi & Bangunan Tunggal \\
10 & Kalasan & CB & Unmovable & Candi & Bangunan Tunggal \\
11 & Kalongan & Belum CB & Movable & Komponen candi & Non-bangunan \\
12 & Kedulan & CB & Unmovable & Candi & Kompleks Bangunan \\
13 & Kelurak & Belum CB & Movable & Prasasti & Non-bangunan \\
14 & Kulon & Belum CB & Movable & Komponen candi & Non-bangunan \\
15 & Lumbung & CB & Unmovable & Candi & Kompleks Bangunan \\
16 & Ngaglik & Belum CB & Movable & Komponen candi & Non-bangunan \\
17 & Pakem & Belum CB & Movable & Komponen candi & Non-bangunan \\
18 & Patihan & Belum CB & Movable & Komponen candi & Non-bangunan
\end{tabular}


Prediksi Dampak Jalan Tol terhadap Situs Arkeologi di Kecamatan Kalasan/Janati Prariyadiyani, Andri Kurniawan, M. Baiquni

\begin{tabular}{l|lllll}
19 & Plaosan Kidul & CB & Unmovable & Candi & Kompleks Bangunan \\
20 & Plaosan Lor & CB & Unmovable & Candi & Kompleks Bangunan \\
21 & Prambanan & CB & Unmovable & Candi & Kompleks Bangunan \\
22 & Randugunting & Belum CB & Movable & Komponen candi & Non-bangunan \\
23 & Rejo & Belum CB & Movable & Komponen candi & Non-bangunan \\
24 & Ringinsari & Belum CB & Movable & Komponen candi & Non-bangunan \\
25 & Sambiroto & Belum CB & Movable & Komponen candi & Non-bangunan \\
26 & Sambisari & CB & Unmovable & Candi & Kompleks Bangunan \\
27 & Sari & CB & Unmovable & Candi & Bangunan Tunggal \\
28 & Sewu & CB & Unmovable & Candi & Kompleks Bangunan \\
29 & Sojiwan & CB & Unmovable & Candi & Kompleks Bangunan \\
30 & Somodaran & Belum CB & Movable & Komponen candi & Non-bangunan \\
31 & Tegalrejo & Belum CB & Movable & Komponen candi & Non-bangunan \\
32 & Watugudig & CB & Movable & Komponen candi & Non-bangunan \\
\hline
\end{tabular}

Sumber: Mundardjito (1993)

Melalui hubungan kedekatan (proximity) antara kedua aspek pengamatan tersebut beserta masingmasing variabelnya analisis ini akan menghasilkan tiga kriteria dampak yang masing-masing mempertimbangkan sisi positif dan negatifnya, yakni:

\section{Terdampak langsung, yakni memperoleh keuntungan atau kerugian akibat pembangunan jalan tol dan fasilitas pendukungnya}

2. Terdampak tidak langsung, yakni memperoleh keuntungan atau kerugian akibat perkembangan jalan lain, khususnya jalan-jalan kabupaten yang sekarang ada, yang memperlancar akses atau memiliki konektivitas ke jalan tol.

\section{Tidak terdampak}

Hubungan antara kriteria dampak (langsung atau tidak langsung) dan sifat dampak (positif atau negatif dapat dilihat pada Tabel 4.

Tabel 4. Bentuk-bentuk dampak berdasarkan kriteria dan sifat dampak

\begin{tabular}{|c|c|c|}
\hline Dampak & Negatif & Positif \\
\hline $\begin{array}{l}\text { Langsung } \\
\text { (dampak pembangunan jalan } \\
\text { tol) }\end{array}$ & $\begin{array}{l}\text { 1. Kehilangan data } \\
\text { 2. Kerusakan konteks } \\
\text { data }\end{array}$ & $\begin{array}{l}\text { 1. Visibility objek makin } \\
\text { jelas } \\
\text { 2. Perbaikan akses ke } \\
\text { objek }\end{array}$ \\
\hline $\begin{array}{l}\text { Tidak Langsung } \\
\text { (dampak perkembangan } \\
\text { jalan nasional dan } \\
\text { kabupaten) }\end{array}$ & $\begin{array}{l}\text { 1. Kehilangan data } \\
\text { 2. Kerusakan } \\
\text { konteks data }\end{array}$ & $\begin{array}{l}\text { 1. Visibility objek makin } \\
\text { jelas } \\
\text { 2. Perbaikan akses ke } \\
\text { objek }\end{array}$ \\
\hline
\end{tabular}

Keterangan:

\section{Dampak negatif}

1. Kehilangan data: Kondisi hilangnya data akibat pekerjaan konstruksi jalan

2. Kerusakan konteks data: Kondisi perubahan susunan atau asosiasi antar data akibat pekerjaan konstruksi jalan

\section{Dampak Positif}

1. Visibility objek makin jelas:Tersedianya ruang yang makin lapang dan tertata untuk menikmati objek

2. Perbaikan akses ke objek: Tersedianya sarana jalan yang lebih lebar dan tertata semakin mempermudah akses publik ke masing-masing objek 
Prediksi Dampak Jalan Tol terhadap Situs Arkeologi di Kecamatan Kalasan/Janati Prariyadiyani, Andri Kurniawan, M. Baiquni

\section{Hasil dan Pembahasan}

Wilayah Kalasan yang memiliki banyak situs arkeologi menjadi salah satu dari enam kecamatan di DIY yang nantinya dilewati Jalan Tol SoloYogyakarta, khususnya wilayah Desa Selomartani, Tamanmartani, Tirtomartani, dan Purwomartani. Sebagai wilayah perbatasan antarprovinsi kekayaan arkeologis serupa juga dijumpai di wilayah Prambanan, Kabupaten Klaten, Jawa Tengah yang juga tercakup di KCB Prambanan (Dirjenbud 2016). Sebanyak 32 situs arkeologi di dua wilayah ini sebagian sudah ditetapkan sebagai CB (sebanyak 15 candi) dan sebagian lainnya masih dalam dugaan sebagai CB. Himpunan situs inilah yang menjadikan Klaster KalasanPrambanan sebagai wilayah dengan sensitivitas tertinggi di DIY dalam hal potensi arkeologisnya (Yuwono 2015).

Sensitivitas yang dimaksud dihitung berdasarkan tiga variabel, yakni: (1) jarak antar situs; (2) jumlah situs dalam setiap grid (1 km²); dan (3) properti atau kategori situs di setiap grid yang dibedakan antara kompleks bangunan, bangunan tunggal, dan nonbangunan. Semakin tinggi nilai total dari ketiga variabel tersebut, atau semakin tinggi sensitivitas, berarti semakin besar potensi ditemukannya data baru (Yuwono 2015). Pemodelan prediktif tersebut menggunakan model yang dikembangkan oleh Gibbon dalam proyek Minesota Archaeological Predictive Model yang mengukur besar-kecilnya potensi temuan data arkeologi berdasarkan tingkat sensitivitasnya (Gibbon 2007).

$$
\text { Berdasarkan Keputusan }
$$

Gubernur DIY Nomor 206/KEP/2020, ada dua jenis konstruksi jalan tol yang akan dibangun di melintasi wilayah Kalasan, yaitu at grade dan elevated. Konstruksi at grade yang dibuat menyusuri permukaan lahan dibangun mulai wilayah perbatasan DIY-Jawa Tengah di Desa Tamanmartani hingga Desa Purwomartani di sebelah utara Selokan Mataram. Konstruksi at grade lainnya direncanakan mulai dari Selokan Mataram ke arah tenggara melewati Desa Tirtomartani hingga Desa Bokoharjo. Adapun konstruksi elevated dibangun di atas Selokan Mataram di Desa Purwomartani ke arahbarat.

Dengan demikian terdapat tiga segmen atau ruas tol yang akan dibangun, yakni: (1) Ruas TirtomartaniPurwomartani (at grade), (2) Ruas Selokan Mataram (elevated). Di luar kedua ruas tersebut akan dibangun ruas lain dari Selokan Mataram ke arah tenggara yang tersambung dengan jalur tol Prambanan-Piyungan, yakni (3) Ruas Selokan Mataram-Bokoharjo (atgrade) (Gambar 3).

$$
\text { Kajian ini berhasil }
$$

mengelompokkan situs-situs yang terpetakan menjadi terdampak dan tidak terdampak. Situs-situs yang tidak terdampak pembangunan jalan tol dan perkembangan jalan sekitarnya terdiri dari empat klaster (Klaster 1, 2, 3, dan 4). Situs-situs yang terdampak pembangunan jalan tol, baik langsung maupun tidak langsung terdiri dari 3 klaster, yaitu klaster 5, 6, dan 7 seperti terlihat pada Tabel 5 . 
Prediksi Dampak Jalan Tol terhadap Situs Arkeologi di Kecamatan Kalasan/Janati Prariyadiyani, Andri Kurniawan, M. Baiquni

Tabel 5. Pembagian klaster situs

\begin{tabular}{|c|c|c|c|}
\hline KLASTER & SITUS & DAMPAK & KETERANGAN \\
\hline 1 & $\begin{array}{l}\text { Prambanan*/**, Bubrah*, } \\
\text { Sewu*/**,Lumbung*/**, } \\
\text { Gana* }^{*}\end{array}$ & Tidak ada & $\begin{array}{l}\text { Berada di Kawasan PT } \\
\text { Taman Wisata Candi } \\
\text { Prambanan }\end{array}$ \\
\hline 2 & $\begin{array}{l}\text { Banyunibo*/**, Rejo, Plaosan } \\
\text { Lor }^{* / * *}, P l a o s a n \text { Kidul }\left.\right|^{* * *} \\
\text { Sojiwan*/**, Kalongan }\end{array}$ & Tidak ada & $\begin{array}{l}\text { Di luar wilayah DIY } \\
\text { (tidak dianalisis) }\end{array}$ \\
\hline 3 & $\begin{array}{l}\text { Sambiroto, Kadisoka*, } \\
\text { Bromonilan,Pakem, } \\
\text { Randugunting, Patihan }\end{array}$ & Tidak ada & $\begin{array}{l}\text { Di luar buffer jalan } \\
\text { kabupaten }\end{array}$ \\
\hline 4 & $\begin{array}{l}\text { Glondong, Kalasan***, } \\
\text { Bogem,Bugisan }\end{array}$ & Tidak ada & $\begin{array}{l}\text { Di dalam buffer jalan } \\
\text { nasional }\end{array}$ \\
\hline 5 & $\begin{array}{l}\text { Ringinsari, Tegalrejo, } \\
\text { Somodaran,Watugudig }{ }^{*} \text {, } \\
\text { Ngaglik }\end{array}$ & $\begin{array}{l}\text { NEGATIF: bersifat } \\
\text { langsung akibat } \\
\text { pembangunan jalan tol }\end{array}$ & $\begin{array}{l}\text { Kehilangan data dan } \\
\text { kerusakan konteks data }\end{array}$ \\
\hline 6 & Cupuwatu, Kelurak & $\begin{array}{l}\text { NEGATIF: bersifat tidak } \\
\text { langsung akibat } \\
\text { perkembangan jalan } \\
\text { kabupaten }\end{array}$ & Kerusakan konteks data \\
\hline 7 & $\begin{array}{l}\text { Kedulan* }^{* * *}, \text { Sari }^{*}, \\
\text { Sambisari*/**}, \text { Kulon }\end{array}$ & $\begin{array}{l}\text { NEGATIF dan POSITIF: } \\
\text { bersifat tidak langsung } \\
\text { akibat perkembangan } \\
\text { jalan kabupaten }\end{array}$ & $\begin{array}{l}\text { Dampak negatif berupa } \\
\text { kerusakan konteks data; } \\
\text { Dampak positif berupa } \\
\text { visibility semakin jelas } \\
\text { dan perbaikan akses ke } \\
\text { objek }\end{array}$ \\
\hline
\end{tabular}

Sumber: Pengolahan Data (2021)

Berdasarkan tabel di atas, maka pembahasan lebih ditekankan ke klaster 5, 6, dan 7 yang diprediksi memiliki dampak. Klaster 5 merupakan klaster yang langsung terdampak oleh pembangunan Jalan Tol Ruas SoloJogjakarta, yaitu JT_01 sepanjang 6,32 $\mathrm{km}$ selebar $90 \mathrm{~m}$. Ruas ini berujung di Selokan Mataram dengan konstruksi at grade (Gambar 4). Dampak negatif yang ditimbulkan berupa kehilangan data dan kerusakan konteks data. Hasil penelitian Mundardjito (1993) menunjukkan adanya tiga situs di jalur JT-01 ini, yaitu Ringinsari, Tegalrejo, dan Somodaran. Ketiganya memiliki temuan berupa batu-batu candi di permukaan yang kemungkinan besar tidak in-situ, meskipun tidak tertutup kemungkinan masih adanya konteks temuan lain yang terpendam.
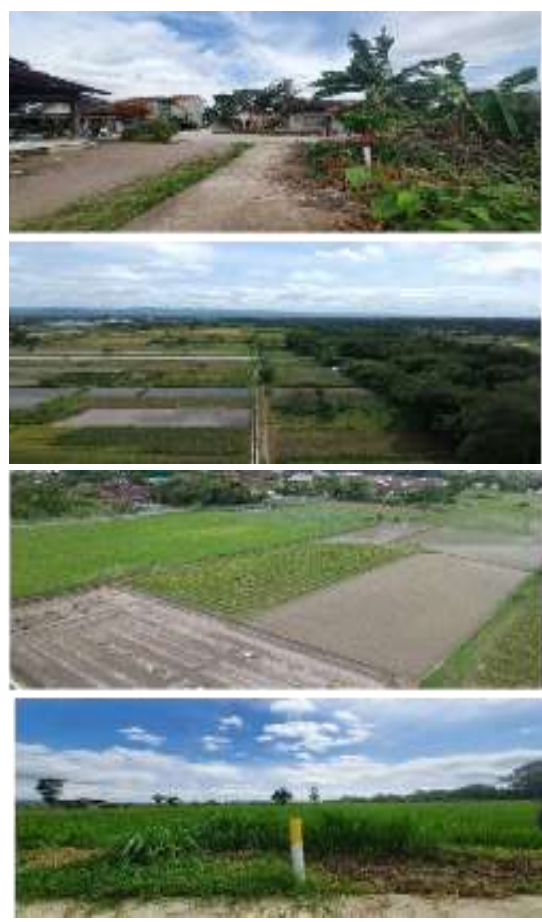

Gambar 4. Foto-foto patok rencana Jalan Tol at grade Solo-Yogyakarta dari ujung timur Selokan Mataram ke arah utara 
Prediksi Dampak Jalan Tol terhadap Situs Arkeologi di Kecamatan Kalasan/Janati Prariyadiyani, Andri Kurniawan, M. Baiquni

Selain ketiga situs tersebut, dua situs lain di klaster 5 juga menghadapi ancaman yang sama, yaitu dampak negatif secara langsung berupa kehilangan data dan kerusakan data. Kedua situs tersebut yakni Watugudig dan Ngaglik yang terdampak langsung oleh pembangunan ruas tol JT_03 sepanjang 3,35 $\mathrm{km}$ dari lingkar susun Selokan Mataram menuju ke arah tenggara yang merupakan jalur Yogkyakarta-Cilacap. Bahkan, salah satu dari situs tersebut, yaitu Watugudig adalah situs yang sudah ditetapkan sebagai CB.

Dampak negatif secara tidak langsung akibat perkembangan jalan kabupaten kemungkinan dialami oleh dua situs di Klaster 6, yaitu Cupuwatu dan Kelurak. Situs Cupuwatu terletak di bagian baratdaya area penelitian di sebelah timur Jalan UKRIM (JK_11). Kemungkinan dampak paling besar berupa kerusakan konteks data yang masih berada di bawah tanah. Adapun Situs Kelurak terletak di sebelah barat Kompleks Prambanan di sepanjang Jalan Karangmojo (JK_03). Situs ini merupakan lokasi temuan Prasasti Kelurak yang kemungkinan besar masih memiliki konteks temuan lainnya mengingat lokasinya dengan dengan komplek percandian besar. Oleh karena itu, adanya dampak yang secara tidak langsung bersifat negative akibat pembangunan jalan kabupaten pantas perhitungkan.

Klaster 7 merupakan klaster terpenting dalam penelitian ini karena memiliki empat candi yang tiga di antaranya sudah ditetapkan sebagai CB, yaitu Candi Kedulan, Sari dan Sambisari. Bahkan Kedulan dan Sambisari merupakan kompleks percandian. Adapun satu candi lainnya, yaitu Candi Kulon belum dipugar dan belum ditetapkan sebagai $\mathrm{CB}$, tetapi memiliki arti penting sebagai bagian dari Candi Sewu. Dampak tidak langsung baik yang bersifat negatif maupun positif akibat perkembangan jalan kabupaten diprediksi akan berpengaruh terhadap candi-candi tersebut. Dampak negative berupa kerusakan konteks data Adapun dampak positis berupa visibiliti objek yang semakin jelas untuk dinikmati oleh publik. Di samping itu, dengan berkembangnya jalan-jalan kabupaten di sekitar situs akses publik ke lokasilokasi candi juga semakin meningkat. Hal ini tentunya mendukung upaya pemasaran dan pemsyarakatan candicandi tersebut sebagai objek wisata.

Candi Kedulan, selain letaknya tidak jauh dari jalan tol (JT_01) juga berdekatan dengan dua jalan kabupaten, yaitu Jalan Raya LPMP (JK_05) di sebelah timur dan Jalan Raya Kalimati (JK_07) di sebelah selatannya. Hal ini tentunya akan menguntungkan dan mendukung pengenalan dan pengembangan objek wisata candi bagi masyarakat luas. Apalagi jika nantinya didukung prasarana fisik dan penataan yang memadai, termasuk penataan untuk pengembangan dan pemanfaatan melalui zonasi dan penyusunan master plan situs (Gambar 5).

Zonasi merupakan teknik pembagian atau pemecahan suatu kawasan menjadi beberapa bagian berdasarkan fungsi, kondisi, dan potensinya agar dapat diterapkan pengelolaan yang tepat, efektif, dan sesuai dengan tujuannya (Muta'ali 2013: 350). Seperti tercantum di dalam 
Prediksi Dampak Jalan Tol terhadap Situs Arkeologi di Kecamatan Kalasan/Janati Prariyadiyani, Andri Kurniawan, M. Baiquni

PP 13/2017, Pasal 103 Ayat 3, peraturan zonasi untuk kawasan cagar budaya disusun dengan memperhatikan dua hal, yakni: (a) Pemanfaatan untuk pariwisata, penelitian dan pengembangan, serta ilmu pengetahuan dan (b) Ketentuan pelarangan kegiatan dan pendirian bangunan yang tidak sesuai dengan fungsi kawasan. Dengan demikian, tujuan yang dimaksud dalam uraian Muta'ali kurang lebih untuk mengurangi dampak negatif pembangunan jalan tol terhadap kelestarian situs dan memaksimalkan dampak positif untuk pengembangan wilayah sekitar situs.
Candi Kedulan, dengan wilayah
terbangun yang paling sempit dibandingkan lingkungan candi-candi lainnya memungkinkan dibuat zonasi palinng detil , meliputi Zona Inti, Zona Penyangga, dan Zona Pengembangan. Zonasi seperti ini sejalan dengan UU $11 / 2010$ tentang CB yang menempatkan zonasi sebagai bagian dari upaya perlindungan $\mathrm{CB}$ untuk mencegah dan menanggulanginya dari kerusakan, kehancuran, atau kemusnahan (Pasal 1 Ayat 23). Upaya ini ditempuh dengan penentuan batasbatas keruangan situs dan/atau kawasan CB sesuai dengan kebutuhan (Pasal 1 Ayat 26).
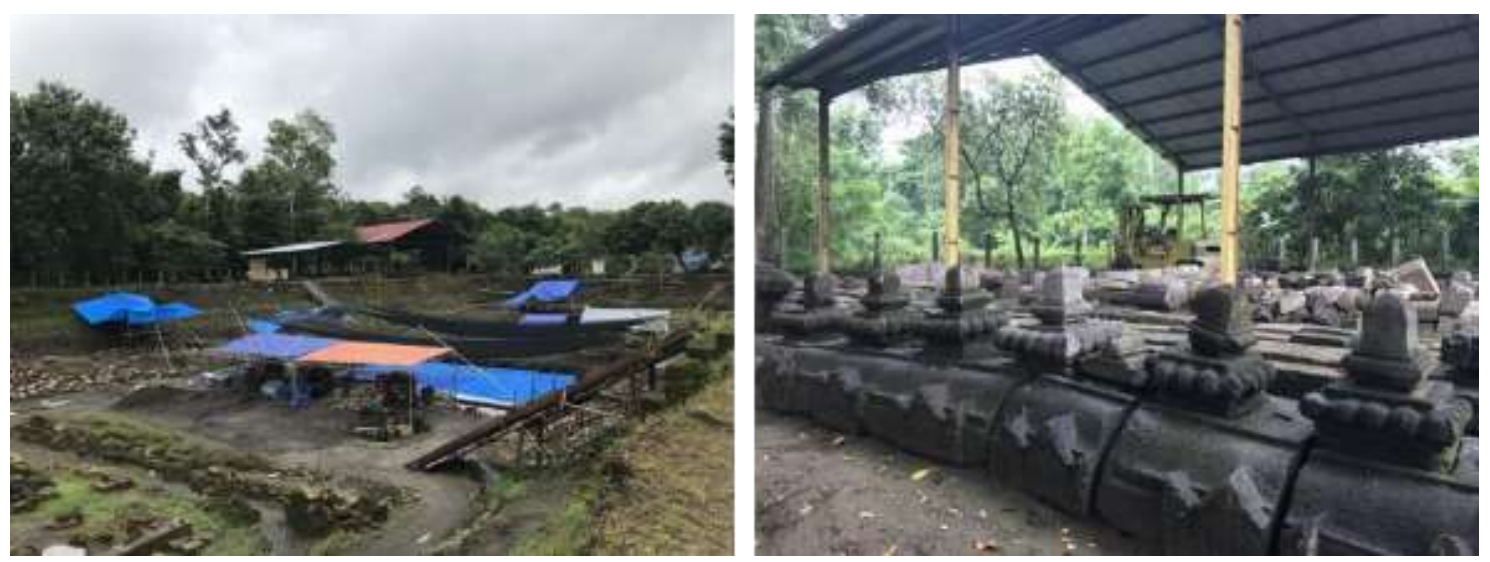

Gambar 5. Foto-foto Candi Kedulan pada saat dilakukan pemugaran tahun 2018

Candi Sari (Gambar 6) yang terletak di sepanjang jalan nasional (JN_01) pada kenyataannya tidak begitu dikenal masyarakat luar karena berada di tengah permukiman, berbeda dengan Candi Kalasan yang terletak di sisi lain dari jalan yang sama. Perkembangan jalan kabupaten khususnya Jalan Selokan Mataram (JK_29) dan Jalan Raya LPMP (JK_05), diprediksi akan lebih membuka akses ke lokasi candi ini.

Candi Sambisari (Gambar 7)
diprediksi akan memperoleh
keuntungan atau dampak positif akibat
perkembangan Jalan Candi Sambisari
(JK_13), Jalan Ruko Sambisari
(JK_14), dan Jalan Purwomartani
(JK_16). Ketiga ruas jalan ini menjadi
jalan utama yang menghubungkan
jalan nasional dan kawasan
permukiman Purwomartani yang
sekarang menjadi kawasan padat,
bukan hanya secara demografis, tetapi
juga secara ekonomis. Ketiga ruas


Prediksi Dampak Jalan Tol terhadap Situs Arkeologi di Kecamatan Kalasan/Janati Prariyadiyani, Andri Kurniawan, M. Baiquni

jalan yang sekarang sudah dibuat melingkar, menghindari lokasi Candi Sambisari ini menjadi modal kuat untuk zonasi pengembangan dan pemanfaat dengan memanfaatkan perkembangan jalan yang akan terjadi.

Beberapa penelitian terdahulu menyebutkan bahwa pembangunan jalan tol akan mematikan wilayah yang dilewatinya. Perkembangan ekonomi dan sosial hanya dapat dinikmati oleh kota-kota yang terhubung melalui jalur tol tersebut. Tol Cipularang yang menghubungkan Jakarta dan Bandung dijadikan contoh kasus tersebut (Radiansyah dkk. 2017: 354;). Pernyataan serupa juga dikemukakan oleh oleh Prasetyo dan Djunaedi (2019: 61 dan 73), bahwa pembangunan jalan
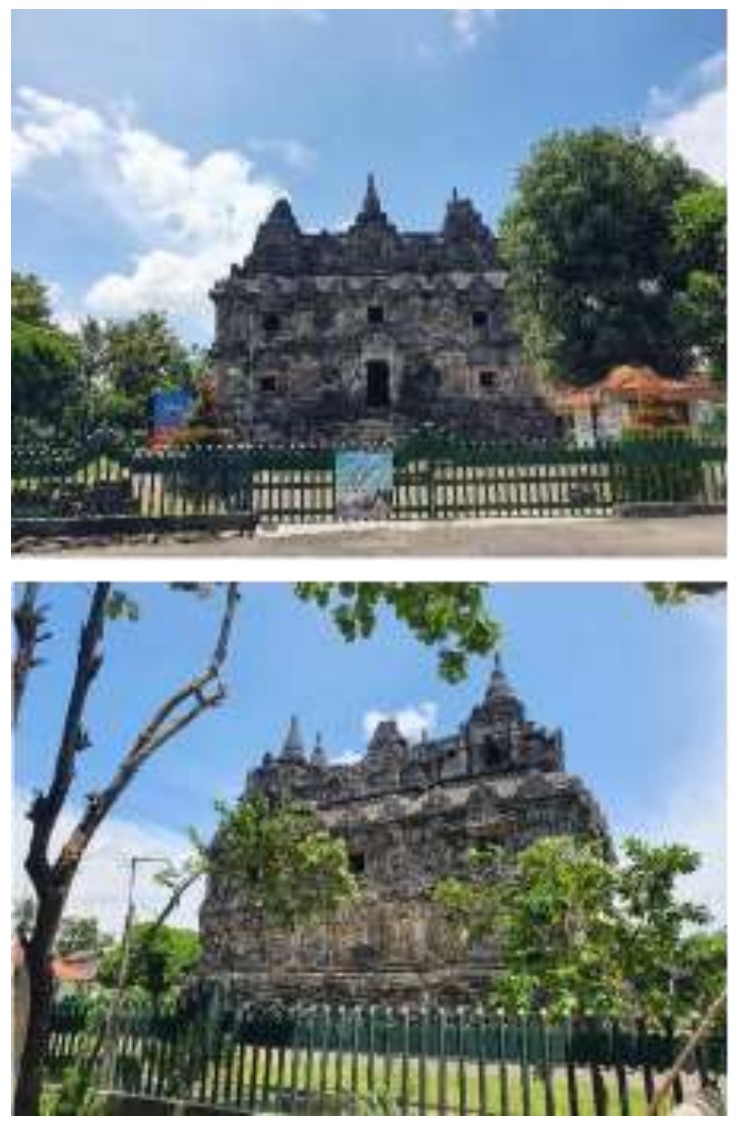

tol lebih banyak dinikmati oleh wilayahwilayah ujung yang menjadi tujuan pergerakan. Pada wilayah-wilayah tersebut pertumbuhan dan aktivitas ekonomi cenderung meningkat pesat, sementara wilayah tengah yang hanya terlewati jalan tol cenderung mengalami penurunan ekonomi.

Menurut penulis kasus seperti ini kecil kemungkinannya terjadi pada jalur tol Solo-Yogyakarta yang melewati wilayah Kalasan. Dampak positif justru akan banyak dinikmati wilayah percandian ini sebagai modal pengembangan wisata budaya. Apalagi dua pintu tol yang akan dibangun di sana memungkinkan area percandian ini untuk lebih mudah diakses publik pemakai jalan tol.
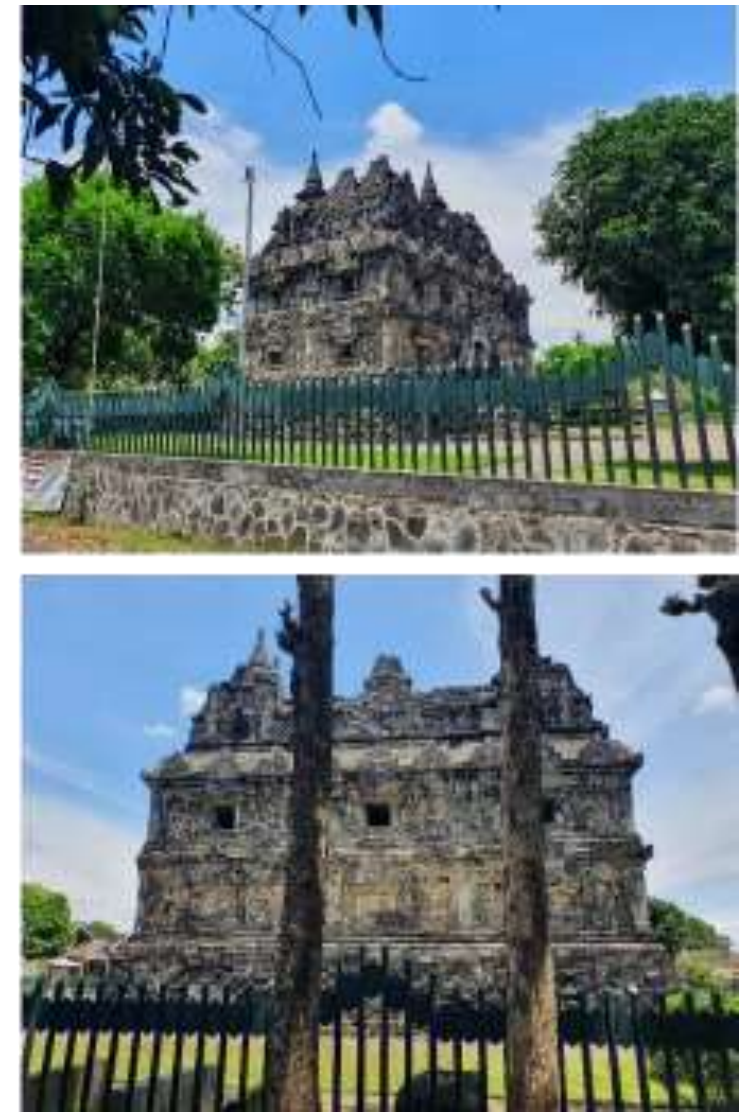

Gambar 6. Foto-foto Candi Sari tahun 2021 
Prediksi Dampak Jalan Tol terhadap Situs Arkeologi di Kecamatan Kalasan/Janati Prariyadiyani, Andri Kurniawan, M. Baiquni
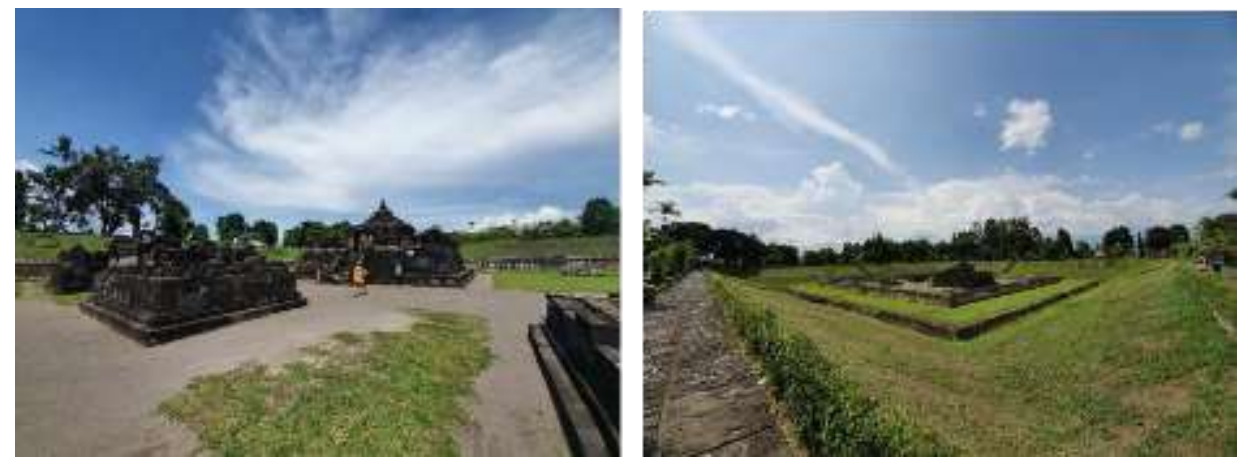

Gambar 7. Foto-foto Candi Sambisari

\section{Penutup}

Penelitian ini memperoleh
kesimpulan bahwa pembangunan jalan tol sebagaimana ditetapkan melalui Keputusan Gubernur DIY Nomor 206/KEP/2020 tidak berdampak besar terhadap situs-situs arkeologi, apalagi yang sudah ditetapkan sebagai CB. Dampak langsung berupa kehilangan dan kerusakan konteks data hanya dialami oleh situs-situs yang berisi komponen candi sebagai temuan lepas. Kasus ini dialami situs-situs di sepanjang jalur JT_01 yang selama ini tidak pernah diprioritaskan untuk diteliti. Bagi arkeologi, pembangunan jalan tol justru memberikan beberapa keuntungan untuk mengembangkan $\mathrm{CB}$ sebagai asset budaya dan pariwisata. Prioritas untuk memetakan potensi arkeologis menjadi tuntutan dalam pengembangan assessment situs. Kondisi seperti itu selama ini belum tercipta. Kurangnya kesiapan akan data termasuk di dalamnya belum tersedianya peta sebaran potensi situs, baik secara prediktif maupun eksisting seringkali menjadi penghambat kecepatan arkeologi dalam

mengimbangi laju pembangunan infrastruktur. Hak seperti ini yang antara lain menyebabkan tarik ulur di dalam penetapan jalur tol SoloYogyakarta. Perancangan konstruksi elevated pada ruas tol JT_02 di sepanjang Selokan Mataram merupakan Langkah maju dari pemerintah yang justru belum dipertimbangkan oleh arkeologi. Selama ini Selokan Mataram yang memiliki nilai sejarah tinggi dari akhir masa kolonialisme Jepang justru belum ditetapkan sebagai CB. Penghargaan pemerintah dalam melindungi data sejarah dengan merancang konstruksi elevated di atas jalur Selokan Mataram ini perlu disikapi oleh arkeologi melalui penetapan Selokan Mataram sebagai Cagar Budaya.

\section{Daftar Pustaka}

Achmadi, S. (2014). Pemeringkatan Cagar Budaya Tidak Bergerak. Jurnal Konservasi Cagar Budaya, 8(1), 72-81. doi: 10.33374/jurnalkonservasicagarb udaya.v8i1.126

Adhiguno, L. (2019). Peran Dinas Pertanahan dan Tata Ruang dalam Alih Fungsi Tanah Pertanian Menjadi Tanah Non 
Prediksi Dampak Jalan Tol terhadap Situs Arkeologi di Kecamatan Kalasan/Janati Prariyadiyani, Andri Kurniawan, M. Baiquni

Pertanian di Kabupaten Sleman (Skripsi). Yogyakarta: Universitas Islam Indonesia.

Ashmore, W., \& Sharer, R. (2010). Discovering Our Past (5th ed.). New York: McGraw-Hill.

Bemmelen, R. (1970). The Geology of Indonesia. The Hague: Martinus Nijhoft.

Bowersox, D., Calabro, P., \& Wagenheim, $\quad G$. (1981). Introduction to Transportation. New York: Macmillan.

BPS Provinsi DIY. (2019). Kabupaten Sleman dalam Angka Tahun 2019. Yogyakarta: BPS Provinsi Yogyakarta.

Boechari. (2012). Melacak Sejarah Kuno Indonesia Lewat Prasasti. Jakarta: Kepustakaan Populer Gramedia, hal. 273-290.

Budiharsono, S. (2001). Teknik Analisis Pembangunan Wilayah Pesisir dan Lautan. Jakarta: Pradnya Paramita.

Carman, J. et al. (1995). Introduction: Archaeological Management, in M. Cooper, A. Firth, J. Carman \& D. Wheatley (eds) Managing Archaeology, London: Routledge, pp. 1-15.

Cleere, H. F. (1989). Introduction: the rationale of archaeological management, in Henry F. Cleere (ed.), Archaeological Heritage Management in The Modern World. London: Unwin-Hyman.

Creswell, J. W. (2014). Research Design Pendekatan Kualitatif, Kuantitatif, dan Mixed (edisi ketiga). Yogyakarta: Pustaka Pelajar.

Degroot, V. (2009). Candi, Space and Landscape: A Study on the Distribution, Orientation and Spatial Organization of Central Javanese Temple Remains. Leiden: Mededelingen van het Rijk's Museum voor Volkenkunde.
Gamble, C. (2001). Archaeology: The Basic. London: Routledge.

Gibbon, G. (2002). Mn/Model Final Report Chapter 2: Research Design and Project Time Line. Retrieved 27 April 2021, from https://www.dot.state.mn.us/mnm odel/P3FinalReport/app a.html

Highway Agency and English Heritage. (2007). Assessing the Effect of Road Schemes on Historic Landscape Character. England: Halcrow Group Limited for the Highways Agency 2007.

Husein et al. (2010). Georadar Investigation at The Kedulan Temple Excavation Site, Kalasan, Yogyakarta, J.SE Asian Appl. Geol., 2(1), 47-55.

Johnson, M. (2007). Ideas of Landscape. Oxford: Blackwell Publishing Ltd.

Kusumaningsih, S. I. (2017). Partisipasi Masyarakat Dalam Kajian Zonasi Kawasan Candi Kalasan Desa Tirtomartani, Kecamatan Kalasan, Kabupaten Sleman, Daerah Istimewa Yogyakarta, (Tesis). Yogyakarta: Universitas Gadjah Mada.

Kamermans H., \& Oberendorff, M. (2009). Archaeological Prediction and Risk Management. Leiden: Leiden University Press.

Kementrian Pendidikan dan Kebudayaan Indonesia. (2013). Candi Indonesia Seri Jawa. Jakarta: Direktorat Pelestarian Cagar Budaya dan Permuseuman, Direktorat Jenderal Kebudayaan,

Kementerian Pendidikan dan Kebudayaan.

Longacre, W. A. (2010). Archaeology as anthropology revisited. Journal of Archaeological Method and Theory, 17(2), 81-100.

Mundardjito. (2002). Pertimbangan Ekologis Penempatan Situs Masa Hindu-Buda di Daerah 
Prediksi Dampak Jalan Tol terhadap Situs Arkeologi di Kecamatan Kalasan/Janati Prariyadiyani, Andri Kurniawan, M. Baiquni

Yogyakarta. Jakarta: Wedatama Widya Sastra.

Newhall, C.G. et al. (2000). 1000 years of explosive of Merapi Volcano, Central Java: Archaeological and modern implications. Journal of Volcanology and Geothermal Research. 100, 9-50.

Octorio, A., \& Christanto, J. (2014). Faktor-Faktor yang Mempengaruhi Pola Sebaran Perumahan di Kabupaten Sleman. Jurnal Bumi Indonesia, 3(3).

Pemerintah Daerah Istimewa Yogyakarta. (2019). Peraturan Daerah Istimewa Yogyakarta Nomor 5 Tahun 2019 tentang Rencana Tata Ruang Wilayah Daerah Istimewa Yogyakarta Tahun 2019 - 2039. Yogyakarta: Pemda DIY.

Pemerintah Daerah Istimewa Yogyakarta. (2020). Peraturan Gubernur Daerah Istimewa Yogyakarta (DIY) Nomor: 206/KEP/2020, Tanggal 10 Juli 2020, tentang Penetapan Lokasi Pembangunan Jalan Tol SoloYogyakarta di DIY. Yogyakarta: Pemda DIY.

Prasetyo, S. A., \& Djunaedi, A. (2019). Perubahan perkembangan wilayah sebelum dan sesudah pembangunan jalan tol. Jurnal Litbang Sukowati vol. 3 (1), hal. 61-74.

Prasodjo, T., \& Yuwono, J. S. E. (2019). Dawuhan, Wluran, dan Pañcuran: Penelusuran Aspek Hidrologi terhadap Isi Prasasti Tlu Ron, dalam Menggores Aksara, Mengurai Kata, Menafsir Makna. Yogyakarta: Departemen Arkeologi Fakultas IImu Budaya Universitas Gadjah Mada, hal.1031.

Purbawinata, M. A., et al. (2007). Understanding Merapi-type Volcanoes. EOS. 88(1\&2). The
American Geophysical Union, p.5-6.

Radiansyah, S., Mulyana, N \& Krisnani, H. (2017). Dampak pembangunan ruas tol Cipularang, Pendekatan sistem sebagai sebuah tawaran solusi. Jurnal Penelitian dan PPM, 4(2), 354-360.

Riyanto, B. (2006). Pengembangan Jaringan Jalan Tol antar Kota dalam Perspektif Sistem Transportasi Berkelanjutan. Media Komunikasi Teknik Sipil, 14(1).

Santoso, E. B. (2012). Perkembangan Node Persinggahan Transportasi pada Sumbu Pengembangan. Planocosmo International Conference Proceeding, SAPPKITB, hal.195-206.

Subandriyo. (2011). Sejarah Erupsi Gunung Merapi dan Dampaknya Terhadap Kawasan Borobudur, dalam Menyelamatkan Candi Borobudur Dari Erupsi Merapi. Hal.85-98. Magelang: Balai Konservasi Borobudur.

Sulistyanto, B., DS Nugrahani, T Prasodjo, JSE Yuwono, AT Hascaryo, D Pradnyawan, A Putranto, R Darmosoetopo, SR Saktimulya, E Mulyantari, J Kurniawan, DR Ekowati, HR Pratama. (2012). Dampak Lahar Dingin Gunung Merapi terhadap Kelestarian Candi-Candi di Prov. D.I. Yogyakarta dan Sekitarnya. Laporan Penelitian Arkeologi. Jakarta: Pusat Arkeologi Nasional.

Tarigan, F., \& Saputra, E. (2013). Analisis Pertumbuhan Moda Transportasi dan Infrastruktur Jalan di Kabupaten Sleman dan Kota Yogyakarta Tahun 20002010. Jurnal Bumi Indonesia, 2(2).

Undang-undang Republik Indonesia Nomor 11 tahun 2010 tentang 
Prediksi Dampak Jalan Tol terhadap Situs Arkeologi di Kecamatan Kalasan/Janati Prariyadiyani, Andri Kurniawan, M. Baiquni

Cagar Budaya.

Undang-undang Republik Indonesia Nomor 26 tahun 2007 tentang Penataan Ruang.

Verhagen, P. (2007). Case Studies in Archaeological Predictive Modelling. Leiden: Leiden University Press.

Verhagen, P., \& Whitley, T. (2012). Integrating Archaeological Theory and Predictive Modeling: A Live Report from the Scene. Journal of Archaeological Method and Theory, 19(1), 49-100. Retrieved June 28, 2021, from http://www.jstor.org/stable/41408 809

Zuidam, R. A van. (1985). Aerial PhotoInterpretation in Terrain Analysis and Geomorphological Mapping. The Hague: Smits Publisher. 